\title{
UPAYA PENINGKATAN KEMAMPUAN SISWA KELAS X \\ PROGRAM KEAHLIAN TEKNIK BANGUNAN \\ DENGAN MODEL TUTOR SEBAYA (PEER TUTORING) \\ PADA MATA PELAJARAN GAMBAR TEKNIK \\ DI SMK N 5 SURAKARTA
}

\author{
Qusnul Angga Rosita ${ }^{1}$, A.G. Tamrin ${ }^{2}$, Chundakus Habsya ${ }^{3}$ \\ Pendidikan Teknik Bangunan, Universitas Sebelas Maret \\ e-mail: qusnul.angga@yahoo.com
}

\begin{abstract}
The purpose of this study was to determine: (1) Improving student learning outcomes in subjects Engineering Drawing by using Peer Tutoring learning model in class $X$ Civil Engineering Program in SMK N 5 Surakarta. (2) The effectiveness of the application of the Peer Tutoring learning model in subjects Engineering Drawing in class X Civil Engineering Program SMK N 5 Surakarta.

This study is a classroom action research conducted in class $\mathrm{X}$ Civil Engineering Program in SMK N 5 Surakarta with 31 students. This study was conducted in two cycles. Each cycle consists of a phase of implementation, observation and reflection. The instrument used in this study consisted of a test of learning outcomes and assessment sheets of observation. Test the data validity by using member check and analyze data by using interactive analysis, which consists of: data reduction, data presentation, drawing conclusions or verification.

The results research with Peer Tutoring model indicate improvement of cognitive is $15.49 \%$; psychomotor domains is $20.26 \%$; affective is $20 \%$; and effectiveness of learning increased up to $8.52 \%$.
\end{abstract}

Key word : Peer Tutoring, Learning outcomes, and Effectiveness

\footnotetext{
${ }^{1}$ Mahasiswa Program Studi Pendidikan Teknik Bangunan FKIP UNS

${ }^{2}$ Staf Pengajar Program Studi Pendidikan Teknik Bangunan FKIP UNS

${ }^{3}$ Staf Pengajar Program Studi Pendidikan Teknik Bangunan FKIP UNS
} 
PENDAHULUAN

\section{Pendidikan}

merupakan

pondasi dalam kemajuan bangsa serta dasar sebagai cara untuk memajukan atau membawa bangsa di era yang semakin maju. Jalur pendidikan dapat ditempuh dalam dua cara yaitu pendidikan formal dan nonformal. Sekolah merupakan lembaga pendidikan formal yang dituntut untuk melaksanakan proses pembelajaran yang baik secara optimal yang nantinya dapat mencetak generasi muda bangsa yang cerdas, berkarakter dan bermoral tinggi. Salah satu unsur pendukung terjadinya proses pembelajaran adalah seorang pendidik. Interaksi yang diharapkan antara pendidik atau guru dan anak didik atau siswa adalah interaksi yang dapat mendorong semua aktivitas belajar siswa.

Berdasarkan pengamatan

yang dilakukan selama PPL dan observasi di kelas yaitu kelas $\mathrm{X}$ Program Keahlian Teknik Bangunan SMK N 5 Surakarta pada mata pelajaran Gambar Teknik disimpulkan bahwa tingkat keaktifan siswa dan minat siswa dalam mengikuti pembelajaran sangatlah kurang. Siswa merasa bosan terhadap pelajaran Gambar Teknik, karena proses pembelajaran yang berlangsung selama dua jam dihabiskan oleh guru untuk menjelaskan materi pelajaran, sedangkan siswanya sendiri diminta untuk melanjutkan tugas menggambarnya di rumah atau sebagai tugas rumah.

Dari penjelasan tersebut berdampak pada hasil belajar siswa masih kurang memuaskan, yakni siswa yang memperoleh nilai $\geq 75$ masih kurang dari $75 \%$, yaitu untuk ranah kognitif 66,67\%, ranah psikomotorik 66,67\%, dan afektif $60 \%$ dari jumlah 31 siswa kelas $\mathrm{X}$ Teknik Sipil C (TSC) tahun pelajaran 2014/2015.

Menyikapi permasalahan tersebut maka perlu dilakukan penerapan model pembelajaran yang baru sebagai upaya dalam memecahkan masalah pada mata pelajaran Gambar Teknik. Berdasarkan penjelasan diatas model pembelajaran Tutor Sebaya (Peer Tutoring) merupakan salah satu alternatif yang dapat dilakukan oleh seorang guru untuk meningkatkan keaktifan siswa dalam proses 
pembelajaran. Penulis merasa tertarik dengan model pembelajaran Tutor Sebaya (Peer Tutoring) untuk penelitian yang akan dilaksanakan pada mata pelajaran menggambar teknik yaitu dengan judul "Upaya Peningkatan Kemampuan Siswa Kelas X Program Keahlian Teknik Bangunan dengan Model Tutor Sebaya (Peer Tutoring) pada Mata Pelajaran Gambar Teknik di SMK N 5 Surakarta".

\section{TINJAUAN PUSTAKA}

\section{Pembelajaran}

Pembelajaran adalah membelajarkan siswa menggunakan asas pendidikan maupun teori belajar yang merupakan penentu utama keberhasilan pendidikan (Sagala, $2009: 61)$.

Pembelajaran adalah proses interaksi peserta didik dengan pendidik dan sumber belajar pada suatu lingkungan belajar (UU No. 20 Tahun 2003 tentang Sisdiknas Pasal 1 Ayat 20)

Dari beberapa definisi tersebut diatas dapat disimpulkan bahwa pembelajaran adalah proses yang dilakukan guru secara terprogram dalam suatu lingkungan dengan tujuan menciptakan kondisi belajar yang baik dan keberhasilan pendidikan.

\section{Kemampuan}

Menurut Poerwadarminta (2007: 742) mempunyai pendapat lain tentang kemampuan yaitu mampu artinya kuasa (bisa, sanggup) melakukan sesuatu, sedangkan kemampuan artinya kesanggupan, kecakapan, kekuatan.

Jadi kemampuan adalah kekuatan yang dimiliki oleh seseorang atau individu untuk melakukan atau mengerjakan sesuatu.

\section{Hasil Belajar}

$$
\text { Sudjana }
$$

(2009:

mendefinisikan hasil belajar siswa pada hakikatnya adalah perubahan tingkah laku sebagai hasil belajar dalam pengertian yang lebih luas mencakup bidang kognitif, afektif, dan psikomotorik.

Menurut Dimyati dan Mudjiono (2009: 3-4) juga menyebutkan hasil belajar merupakan hasil dari suatu interaksi tindak belajar dan tindak mengajar. Dari sisi guru, tindak mengajar diakhiri dengan proses evaluasi hasil belajar. 
Berdasarkan pengertian hasil belajar diatas dapat ditarik kesimpulan bahwa hasil belajar merupakan kemampuan yang dimiliki oleh masing-masing siswa yang diterima setelah mendapatkan pengalaman belajar dalam kurun waktu tertentu.

\section{Prestasi Belajar}

Menurut Djamarah (1994:

20-21) bahwa prestasi adalah apa yang telah dapat diciptakan, hasil pekerjaan, hasil yang menyenangkan hati yang diperoleh dengan jalan keuletan kerja.

Jadi prestasi belajar adalah kemampuan yang dimiliki oleh siswa dalam proses pembelajaran dengan jangka waktu tertentu sehingga mengalami perubahan baik sikap, tingkah laku, pengetahuan ataupun keterampilan yang diukur dan diwujudkan dalam sebuah angka atau pernyataan.

\section{Efektifitas}

Efektifitas adalah suatu ukuran yang menyatakan seberapa jauh target (kuantitas,kualitas dan waktu) telah tercapai. Dimana makin besar presentase target yang dicapai, makin tinggi efektifitasnya (Hidayat 2009)
Menurut Sinambela (2006:78), pembelajaran dikatakan efektif apabila mencapai sasaran yang diinginkan, baik dari segi tujuan pembelajaran maupun prestasi siswa yang maksimal.

Jadi efektifitas pembelajaran adalah capaian yang dimiliki dalam suatu kegiatan yang dilakukan untuk mendapakan target sesuai dengan indikator keberhasilannya dengan tujuan memperoleh hasil yang maksimal.

\section{Keaktifan}

Keaktifan adalah kegiatan atau aktivitas atau segala sesuatu yang dilakukan atau kegiatan-kegiatan yang terjadi baik fisik maupun non fisik menurut Mulyono (2009: 12).

Jadi keaktifan siswa dalam belajar merupakan semua kegiatan yang dilakukan oleh siswa baik secara fisik maupun non fisik yang terjadi dalam proses belajar mengajar sehingga dapat menciptakan suasana kelas yang nyaman dan kondusif.

\section{Interaksi}

Interaksi merupakan kegiatan timbal balik. Interaksi belajar mengajar berarti suatu kegiatan sosial karena antara peserta didik dan gurunya ada suatu 
komunikasi sosial atau pergaulan (Zahra 1996 :91)

Jadi interaksi merupakan suatu kegiatan yang berlangsung dalam kurun waktu tertentu yang dilakukan oleh antar individu atau beberapa individu yang menimbulkan suatu dampak.

\section{Model}

Model pembelajaran sebagai kerangka konseptual yang digunakan sebagai pedoman dalam melakukan pembelajaran. (Soekamto, dkk, 2000).

Jadi model pembelajaran adalah gambaran selama proses pembelajaran dari awal hingga akhir untuk memberikan pengalaman belajar bagi peserta didik.

\section{Model Tutor Sebaya (Peer Tutoring)}

Dipandang dari tingkat partisipasi aktif siswa, keuntungan belajar secara berkelompok dengan tutor sebaya mempunyai tingkat partisipasi aktif siswa lebih tinggi menurut Ratno Harsanto (2007: 43).

Bantuan belajar oleh teman sebaya dapat menghilangkan kecanggungan. Bahasa teman sebaya lebih mudah dipahami, selain itu dengan teman sebaya tidak ada rasa enggan, rendah diri, malu, dan sebagainya, sehingga diharapkan siswa yang kurang paham tidak segan-segan untuk mengungkapkan kesulitan-kesulitan yang dihadapinya (Sukmadinata, 2007).

Menurut Djamarah (2005: 31) langkah-langkah yang digunakan dalam pembelajaran yang menerapkan bimbingan belajar kelompok dengan tutor sebaya adalah sebagai berikut:

a. Memilih tutor sebanyak 4-5 orang dengan syarat:

- Termasuk dalam peringkat 10 terbaik berdasarkan nilai rapor atau nilai evaluasi sebelumnya.

- Dapat menguasai materi pelajaran.

b. Mengelompokkan siswa menjadi beberapa kelompok.

c. Pengelompokan dilakukan menurut tingkat kecerdasan siswa, yaitu setiap kelompok terdiri dari siswa pandai, sedang dan kurang.

d. Membahas beberapa contoh soal yang berhubungan dengan materi yang diajarkan.

e. Memberikan bimbingan sesuai dengan kesulitan yang dihadapi siswa dengan bantuan tutor sebaya.

f. Mengisi lembar observasi, pengamatan, dan pengidentifikasian siswa selama kegiatan belajar mengajar antara lain: absent, dan keaktifan siswa dalam proses belajar mengajar. 
Mata Pelajaran Gambar Teknik

Gambar Teknik merupakan

salah satu mata pelajaran bagi siswa kelas X SMK Program Keahlian Bangunan dimana pada mata pelajaran ini memberikan materi tentang cara menggambar yang dimulai dari dasar atau awal.

\section{METODE PENELITIAN}

Teknik pengumpulan data yang digunakan yaitu melalui test, observasi, wawancara, dan dokumentasi. Sumber data dalam penelitian ini adalah guru mata pelajaran Gambar Teknik dan siswa kelas X TSC Program Keahlian Teknik Bangunan SMK N 5 Surakarta.

Teknik analisis data dalam penelitian ini dilakukan dari awal sampai akhir kegiatan pengumpulan data. Data dari hasil penelitian diolah dan dianalisis

secara analisis interaktif, yang terdiri dari: reduksi data, penyajian data,

\section{PEMBAHASAN}

\section{Prasiklus}

Dari hasil observasi prasiklus diperoleh data sebagai berikut: a. Rata-rata untuk ranah kognitif sebesar 74,28 dengan persentase ketuntasan sebesar $66,67 \%$ yaitu 20 siswa.

b. Ranah psikomotorik dengan ketuntasan $66,67 \%$ sejumlah 20 siswa dan rata-rata kelas 76,42

c. Untuk ranah afektif terdapat 18 siswa (60\%) yang tuntas dengan rata-rata kelas 74,83

d. Rata-rata efektifitas pembelajaran sebesar $71,03 \%$

\section{Siklus I}

Data hasil penelitian siklus I mengenai penerapan model Tutor Sebaya (Peer Tutoring) pada mata pelajaran Gambar Teknik siswa kelas X $\quad$ TSC SMK N 5 Surakarta diperoleh hasil sebagai berikut :

a. Rata-rata untuk ranah kognitif sebesar 76,67 dengan Persentase ketuntasan sebesar 79,31\% yaitu 23 siswa.

b. Ranah psikomotorik dengan ketuntasan 75,86\% sejumlah 22 siswa dan rata-rata kelas 81,85

c. Untuk ranah afektif terdapat 21 siswa $(72,41 \%)$ yang tuntas dengan rata-rata kelas 77,65

d. Penilaian keaktifan diperoleh rerata capaian ketuntasan klasikal sebesar $77,46 \%$ 


\section{Siklus II}

Siklus II dilakukan untuk melakukan perbaikan atau kekurangan pada siklus sbelumnya. Pada tahap siklus II terjadi perubahan yang cukup baik. Hal ini ditunjukkan dengan meningkatnya hasil belajar dan efektifitas pembelajaran, antara lain :

a. Rata-rata untuk ranah kognitif sebesar 82,5 dengan Persentase ketuntasan sebesar $83,33 \%$ yaitu 25 siswa.

b. Ranah psikomotorik dengan ketuntasan 86,67\% sejumlah 26 siswa dan rata-rata kelas 84,82

c. Untuk ranah afektif terdapat 26 siswa $(86,67 \%)$ yang tuntas dengan rata-rata kelas 80,26

d. Penilaian keaktifan diperoleh rerata capaian ketuntasan klasikal sebesar 79,55\%.

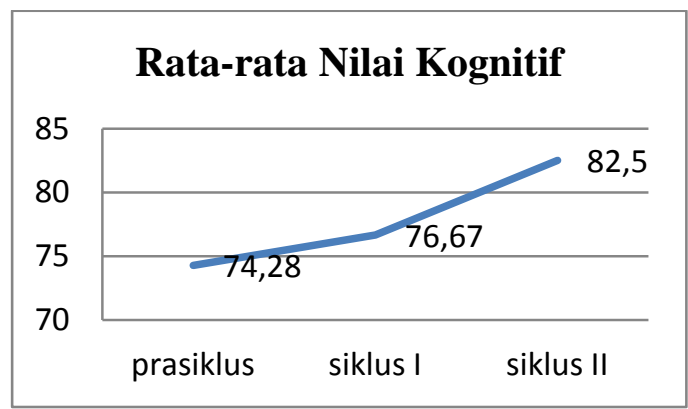

Gambar 4.24 Grafik Perbandingan Rata-rata Nilai Kognitif Prasiklus, Siklus I dan Siklus II

\section{Rata-rata Nilai Psikomotorik}

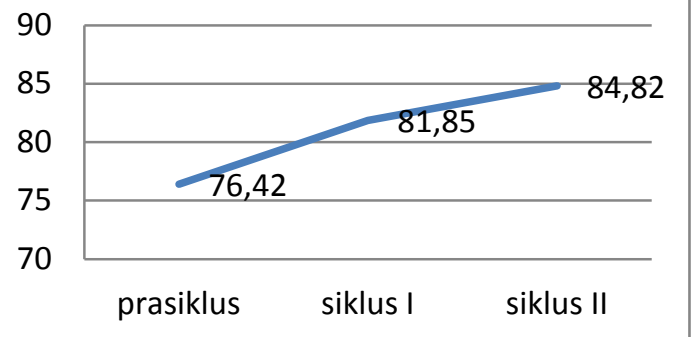

Gambar 4.25 Grafik Perbandingan

Rata-rata Nilai Psikomotorik

Prasiklus, Siklus I dan Siklus II

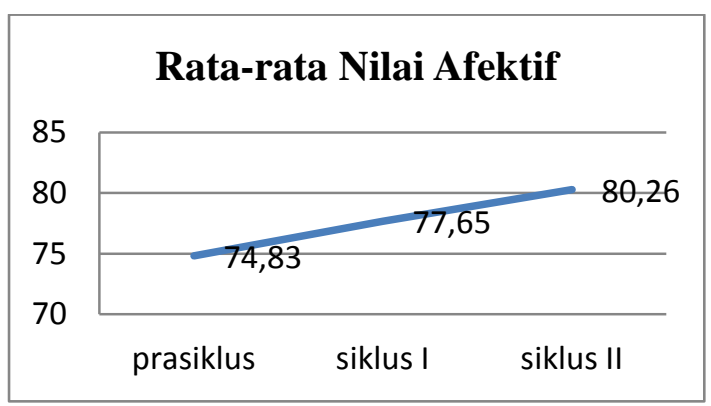

Gambar 4.26 Grafik Perbandingan

Rata-rata Nilai Psikomotorik

Prasiklus, Siklus I dan Siklus II

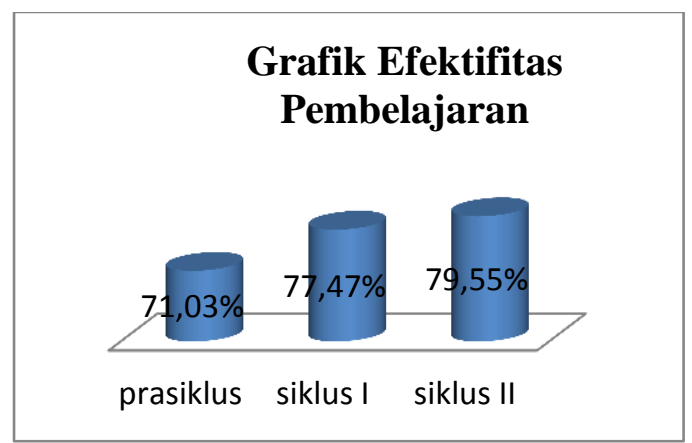

Gambar 4.26 Grafik Capaian Ketuntasan Efektifitas Pembelajaran

Siklus I dan Siklus II

\section{KESIMPULAN}

Berdasarkan hasil penelitian dengan penggunaan model pembelajaran Tutor Sebaya (Peer Tutoring) pada mata pelajaran 
Gambar Teknik siswa kelas $\mathrm{X}$ Program Keahlian Teknik Bangunan di SMK Negeri 5 Surakarta tahun pelajaran 2014/ 2015 menunjukkan bahwa :

1. Adanya peningkatan hasil belajar siswa pada aspek kognitif, afektif, dan psikomotorik yaitu dilihat dari peningkatan nilai siswa dari tahap prasiklus, siklus I, dan Siklus II.

2. Pembelajaran menjadi efektif, karena terjadi peningkatan yang cukup signifikan dari setiap siklusnya.

\section{DAFTAR PUSTAKA}

Dimyati dan Mudjiono. (2009). Belajar dan Pembelajaran. Jakarta: Rineka Cipta.

Djamarah. (1994). Prestasi Belajar Kompetensi Guru, Surabaya: PT Usaha Nasional

Djamarah. (2006). Strategi Belajar Mengajar. Jakarta: Rineka Cipta.

Hidayat. (2009). Pengertian Efektivitas. Diperoleh 10 Juli 2014, dari http:// noebangetz.blogspot.com/2009 /07/definisi-atau-pengertianefektivitas.html.
Http://eprints.ung.ac.id/198/3/20132-86206-151409491-bab211012014045146.pdf

Mulyono. (2009). Pendidikan Bagi Anak Berkesulitan Belajar. Jakarta: Rineka Cipta.

Pemerintah Republik Indonesia. (2003). Undang-Undang Republik Indonesia, No. 20 Tahun 3003 Tentang Sistem Pendidikan Nasional, Jakarta.

Poerwadarminta. (2007). Pengertian Kemampuan. Diperoleh 22 maret 2015 dari

Ratno Harsanto,(2007). Pengelolaan Kelas yang Dinamis, Yogyakarta: Kanisius

Sagala, Syaiful. (2009). Konsep dan Makna Pembelajaran. Bandung: Alfabeta

Sinambela. (2006) Pembelajaran Efektif diperoleh 10 juli 2015 dari

http://eprints.uny.ac.id/8481/3/ bab\%202\%20_08520241028.p df

Sudjana, Nana. (2013). Penilaian Hasil Proses Belajar Mengajar. Bandung : PT.

Remaja Rosdakarya

Sukmadinata. (2007). Model Pembelajaran Tutor Sebaya diperoleh 20 maret 2015 dari: https://bagawanabiyasa.wordpr ess.com/2013/07/21/pembelaja ran-tutor-sebaya/

Soekamto, dkk. (2000). Model Pembelajaran.Diperoleh pada 
tanggal 20 maret 2015 dari:

http://web.iaincirebon.ac.id/si

mak/student/riset/BAB214101

40135.docx

Zahra. (1996). Pengertian interaksi Diperoleh 10 juni 2015 dari: http://digilib.unila.ac.id/7181/1 6/BAB\%20II.pdf 